\title{
ТЕОРЕТИКО-МЕТОДИЧНІ ОСНОВИ ПРОФЕСІЙНОЇ СПРЯМОВАНОСТІ МАЙБУТНІХ СОЦІАЛЬНИХ ПРАЦІВНИКІВ
}

\author{
Іонова І. М., Поляничко А. О.
}

\section{ВСТУП}

Динамічний розвиток науки і соціальних відносин вимагає від сучасних фахівців не тільки грунтовних знань та умінь, але й особистісної включеності в професію, відповідної самоідентифікації, установки на постійне професійне самовдосконалення, ціннісного ставлення до професійної діяльності. Одним із центральних у підготовці майбутніх фахівців стає завдання розвитку і зміцнення їх професійної спрямованості, що передбачає розуміння i внутрішне прийняття цілей професійної діяльності, інтерес і схильність до неї, сформованість професійних ідеалів, переконань і ціннісних орієнтацій. Особливе місце професійна спрямованість посідає в структурі особистості соціальних працівників, від професійної самосвідомості і зорієнтованості яких на гуманістичні цінності професії соціального працівника залежить життя інших людей.

Проблеми спрямованості особистості та пї професійного самовизначення, розглядалися в працях багатьох дослідників (Б. Ананьєв, Ю. Андреєва, Р. Гуревич, Т. Деркач, Т. Ільїна, Н. Кузьміна, А. Сейтешев, В. Сластьонін, В. Якунін та ін.). Питання професійного становлення особистості та розвитку професійно важливих якостей фахівців досліджували О. Борисова, Е. Зеєр, С. Климов, К. Платонов, Б. Ясько та інші. Окремі аспекти професійної спрямованості майбутніх фахівців розглядалися в контексті формування професійної самосвідомості (Л. Григорович, Н. Веселова, С. Кошелева та ін.), професійних інтересів i нахилів (С. Крягжде, О. Прядехо, Б. Федоришин та ін.), ціннісного ставлення до професії (М. Дьоміна).

Дослідники наголошують на особливому значенні професійної спрямованості в процесі професійного і життєвого самовизначення молоді (Ю. Вавілов, В. Журавльов, С. Климов, Б. Федоришин, П. Шавір та ін.). Чільне місце посідають дослідження умов i шляхів формування професійної спрямованості у студентів вищих навчальних закладів (В. Абрамова, Г. Гектіна, Т. Деркач, Н. Дороніна, В. Жернов, В. Потіха).

Аналіз педагогічної та психологічної літератури дає підстави стверджувати, що не зважаючи на значний інтерес науковців до проблеми розвитку професійної спрямованості особистості, вона 
продовжує залишатися актуальною і відкритою для наукового пошуку. Враховуючи результати аналізу психологічної і педагогічної літератури, а також сучасної практики підготовки фахівців у вищих педагогічних навчальних закладах, ми визначили проблему дослідження, що полягає в обгрунтуванні педагогічних умов формування професійно-педагогічної спрямованості майбутніх соціальних працівників.

\section{1. Сутність і зміст формування професійної спрямованості майбутніх соціальних працівників}

Спрямованість пронизує весь життєвий шлях людини і є однією 3 найважливіших властивостей особистості. Аналіз психологопедагогічних досліджень, присвячених проблемі спрямованості особистості, дає підстави стверджувати, що більшість науковців розглядає спрямованість як складне структуроване мотиваційне утворення, що визначає вибіркове ставлення особистості до навколишньої дійсності. Зміст спрямованості вбачається у сукупності домінуючих мотивів, які визначають основну лінію поведінки та діяльності особистості. У структурі спрямованості дослідники виділяють різноманітні компоненти, які мають мотиваційну природу та визначають вибірковість ставлень і поведінки особистості: потреби, інтереси, установки, цілі, ідеали, переконання, прагнення, нахили, потяги, бажання, мотиви тощо.

Якщо загальна спрямованість характеризує сферу всіх потреб i інтересів людини, систему іiї ставлень до дійсності, до інших людей, до самого себе, то професійна спрямованість характеризує сферу тільки тих потреб і інтересів, які пов'язані з вибором професії та майбутньою професійною діяльністю. Професійна спрямованість $€$ важливим аспектом загальної спрямованості особистості, оскільки мотиваційноціннісна сфера дорослої людини формується насамперед у діяльності, що зазвичай має професійний характер. Людині притаманна властивість бути суб'єктом суспільно-трудової діяльності, частковою формою прояву якої $\epsilon$ професійна спрямованість як одна із сторін загальної спрямованості особистості.

Дослідженню професійної спрямованості особистості, iї розвитку в процесі професійної підготовки майбутніх фахівців присвячена значна кількість публікацій і дисертаційних досліджень. Слід зазначити, що поняття «професійна спрямованість» трактується не однозначно. У сучасній психолого-педагогічній літературі професійну спрямованість визначають як: важливу сторону загальної спрямованості особистості, що визначає вибір життєвого шляху; усвідомлену й емоційно виражену зорієнтованість особистості на 
певний вид i рід професійної діяльності; інтегральну властивість особистості, яка характеризує ставлення людини до вибраного фаху, що впливає на підготовку до професійної діяльності й успіх у ній.

Згідно $з$ дослідженнями С. Рубінштейна ${ }^{1}$ професійна спрямованість особистості - це вияв загальної спрямованості у праці, яка розглядається як засіб виховання особистості. Л. Шевченко вважає професійну спрямованість особистості одним із суттєвих компонентів особистості, що виявляється в зосередженості особистості на предметі діяльності, у прагненні глибше пізнати його, вивчити, набути певних знань, умінь, навичок².

В. Прядун визначає професійну спрямованість як інтегроване поняття, яке $\epsilon$ компонентом загальної спрямованості особистості, безпосереднім чином пов'язане 3 мотиваційною сферою людини, яка формує вибіркове позитивне ставлення до професії, особистісне прагнення застосовувати свої знання, досвід, здібності в галузі обраної професії та самореалізуватися в ній ${ }^{3}$.

Професійна спрямованість виявляється у сферах різних професій. Е. Зеєр зазначає, що професійна спрямованість надає всій навчальнотрудовій діяльності майбутнього фахівця глибоко особистісного сенсу, різко підвищуючи якість засвоєння професійних знань, умінь i навичок ${ }^{4}$. Професійна спрямованість $\epsilon$ результатом формування системи ціннісних мотивів, які спонукають особистість до засвоєння професійних знань, умінь, навичок і способів їх творчого використання на практиці. Професійна спрямованість містить у собі предметний зміст і світогляд особистості. Вона $є$ вирішальним чинником під час вибору особистістю майбутньої професії, стійкою властивістю особистості, заснованою на домінуючих мотивах, які спонукають особистість до професійної діяльності. Це сукупність мотивів вибору професії, навчальних мотивів, системи ціннісно-оцінних ставлень особистості до професії і до себе як до професіонала, інтересів, потреб, нахилів, прагнень, пов'язаних з професійною діяльністю людини.

Л. Мітіна розглядає професійну спрямованість як систему емоційноціннісних ставлень, що задають відповідну їх змісту ієрархічну

${ }^{1}$ Рубинштейн С.Л. Проблемы общей психологи. Москва, 1946. 623 с.

2 Шевченко Л.М. Професійна спрямованість: методологічний аспект. Науковий вісник. Київ, 2005. Вип. 88. С. 204-215.

3 Прядун В.О. Поняття професійної спрямованості майбутнього вчителя математики. Наукові записки Серія: Проблеми методики фізико-математичної $i$ технологічної освіти. 2013. № 9. С. 27-31.

4 Зеер Э.Ф. Психология профессионального развития: учеб. пособ. для студентов высших учебных заведений. Москва : Издательський центр «Академия», 2007. 240 c. 
структуру домінуючих мотивів особистості i спонукань до їх утвердження в професійній діяльності. Автор визначає загальні для більшості професій типи спрямованості: на людину, на себе, на предмет діяльності ${ }^{5}$.

Б. Федоришин трактує професійну спрямованість як психологічну готовність людини до вибору напряму майбутньої професійної діяльності $^{6}$. На думку дослідника, професійна спрямованість зумовлюється усвідомленням особистістю вагомих аспектів i особливостей майбутньої професійної діяльності. Вона виявляється в посиленні інтересу до процесів і фактів, що прямо чи опосередковано стосуються певної професії. Інтереси реалізуються в пізнавальній діяльності особистості: накопиченні відповідної інформації (читанні літератури, перегляді фільмів, спілкуванні), участі у відповідних гуртках, навчальній діяльності тощо.

Професійну спрямованість визначають як сторону особистості, що виражається в інтересах, схильностях, намірах, ідеалах і зумовлює мотивовану й цілеспрямовану діяльність під час підготовки до вибору професії. Спочатку виникає професійний інтерес, визначаються стійкі професійні наміри, які сприяють формуванню професійної спрямованості особистості - такою, на думку автора $є$ динаміка цього процесу.

На думку Л. Зибіної, професійна спрямованість $є$ виявом загальної спрямованості особистості, складним багатоплановим процесом, що орієнтує діяльність людини в професійному просторі, надаючи їй стійкості до зовнішніх чинників, відображаючи і зумовлюючи мотиви діяльності, цілі і ставлення до дійсності, опосередковане процесом професіоналізації. Сутність професійної спрямованості особистості проявляється в інтересі до професійної сфери, ставленні до професійної діяльності в цілому і до конкретної професії, а також до процесу професіоналізації, характеру і змісту професійних уявлень ${ }^{7}$.

Л. Бахмат стверджує, що професійна спрямованість виражається в позитивному ставленні особистості до професії; у професійній придатності; професійних інтересах, цінностях; у готовності до

5 Психологическое сопровождение выбора профессии: науч.-метод. пособие / под. ред. Л.М. Митиной. Москва, 1998. 184 с.

6 Профконсультационная работа со старшеклассниками / под. ред. Б. А. Федоришина. М., 2000. 172 с.

7 Зыбина Л.Н. Структурные компоненты и динамики профессиональной направленности личности : дис. ... канд. психол. наук : 19.00.01. Новосибирск, 2009. $317 \mathrm{c}$. 
професійної діяльності, яка заснована на системі ставлень, переконань, мотивів особистості, на її професійній самосвідомості ${ }^{8}$.

Розкриваючи роль професійної спрямованості в розвитку особистості, дослідники аналізують їі функціональні характеристики. Н. Боритко детально описав п'ять функцій професійної спрямованості: інтегральну, системотвірну, цілепокладання, вибірковості, пошукову. Інтегральна полягає у забезпеченні стійкості зв'язків між внутрішніми компонентами спрямованості, завдяки чому у взаємодії з середовищем зберігається ii цілісність; зміна хоча б одного компонента зумовлює зміну інших компонентів або спрямованості загалом. Системотвірна функція спрямованості пов'язана 3 процесом самореалізації особистості, визначає іiї психологічний склад, виступає як квінтесенція самовизначення. Функція цілепокладання полягає в заданні напрямів (смислів, цілей) розвитку особистості, окремих сторін у професійній діяльності і підготовки до неї. Функція вибірковості полягає у визначенні конкретного способу життєдіяльності людини, вибір сфер занять, інтересів, прагнень. Пошукова полягає у визначенні недостатньо розвинених сторін особистості (здібностей, якостей, знань, умінь) і спонуканні до постійного самовдосконалення, опанування досягненнями людської культури ${ }^{9}$.

Інколи професійну спрямованість некоректно ототожнюють 3 позитивним ставленням до професії. Однак саме по собі позитивне ставлення до професії свідчить лише про напрям активності особистості і нічого не говорить про причини такого ставлення, в основі якого можуть лежати різні інтереси, нахили, потреби i прагнення. Лише аналіз системи мотивів, що визначають ставлення до професії, може дати адекватне уявлення про його реальний психологічний зміст. Слід підкреслити, що мотиви, які лежать в основі професійної спрямованості особистості, певним чином організовані. Зазвичай вони утворюють ієрархічну структуру, в якій одні мотиви домінують, інші - відіграють другорядну роль.

Виділяють декілька груп мотивів, які різною мірою пов'язані 3 професійною діяльністю: внутрішні мотиви, які безпосередньо стосуються змісту професії і зумовлені інтересом до неї, коли особистість приваблює передусім процес i прямі результати професійної діяльності; мотиви, які мають більш опосередковане

${ }^{8}$ Бахмат Л.В. Готовність до професійної педагогічної діяльності як наукова проблема. Педагогіка формування творчої особистості у вищій $і$ загальноосвітній школах. 2014. Вип. 34. С. 56-60.

9 Борытко Н.М. Воспитание профессионально-трудовой направленности учащихся старших классов гимназии : автореф. дис. ... канд. пед. наук : 13.00.07. Волгоград, 1992. 19 с. 
відношення до професії і пов'язані 3 формуванням у суспільстві ставлення до неї: усвідомлення суспільної значущості професії, іiі престижності, важливості; мотиви, пов'язані з різноманітними потребами індивіда, що можуть задовольнятися як у професійній діяльності, так і за іiі межами: потреба у самоствердженні, спілкуванні, досягненні, домінуванні тощо; мотиви, що відображають різні аспекти професійної самосвідомості індивіда: впевненість у володінні професійно необхідними якостями і здібностями, у тому, що професія відповідає покликанню; мотиви, в основі яких лежить інтерес до зовнішніх, другорядних ознак професійної діяльності.

На думку П. Шавіра, рівень професійної спрямованості особистості визначається тим, якою мірою провідні мотиви вибору професії відповідають їі об’єктивному змісту, сутнісним особливостям. Високий рівень професійної спрямованості має місце тоді, коли особистість приваблює і цікавить найбільш суттєве в цій професії, те, в чому полягає її сутність і соціальне призначення. Свідченням низького рівня професійної спрямованості $\epsilon$ те, що провідні мотиви вибору професійної діяльності відображають не стільки інтерес до неї, скільки до її зовнішніх, несуттєвих атрибутів ${ }^{10}$.

Професійна спрямованість майбутнього соціального працівника визначається позитивним ставленням до роботи у соціальній сфері. Професійна спрямованість особистості соціального працівника включає інтерес до професії соціального працівника, професійне покликання, професійні наміри та здібності.

Категоріальну сутність професійної спрямованості майбутнього соціального працівника, виходячи 3 його соціальної ролі, необхідно розглядати у площині професійної спрямованості особистості на діяльність у соціальній сфері.

Професійну спрямованість майбутнього соціального працівника можна трактувати як:

- інтегровану характеристику праці соціального працівника, в якій виражається його прагнення до самореалізації, професійного зростання і розвитку в галузі професійної діяльності;

- прагнення особистості стати, бути і залишатися соціальним працівником, яке допомагає йому долати перешкоди та труднощі у своїй роботі;

- систему емоційно-ціннісних ставлень, що визначає структуру стійких домінуючих мотивів особистості соціального працівника

10 Шавир П.А. Психология профессионального самоопределения в ранней юности. Москва : Педагогіка, 19981.96 с. 
(інтересів, нахилів, переконань та інше), які спонукають його до утвердження в професійній діяльності та спілкуванні;

- стійку мотивацію і інтерес до професії, прагнення працювати соціальним працівником.

Професійна спрямованість особистості передбачає розуміння i внутрішнє прийняття нею цілей та завдань, переконань і поглядів. Професійна спрямованість - це якість особистості, яка характеризується стійким інтересом до професії в єдності з суспільною і пізнавальною активністю, що виявляється у прагненні та готовності відповідально виконувати свої професійні обов'язки та функції.

У фундаментальних дослідженнях В. Мерліна ${ }^{11}$, К. Платонова ${ }^{12}$ доведено, що професійна спрямованість як системоутворюючий фактор особистості має змістовну (повнота та рівень) та динамічну (інтенсивність, тривалість, стійкість) характеристики. Під повнотою професійної спрямованості розуміється різноманітність мотивів уподобання професії. Вибіркове ставлення до професії зазвичай розпочинається 3 виникненням приватних мотивів, що пов'язані 3 окремими сторонами змісту певної діяльності або зовнішніми атрибутами професії (кар'єрне зростання, престижність, суспільна значимість, матеріальні та гігієнічні умови праці тощо). Тобто професійна спрямованість заснована на широкому колі потреб, інтересів, ідеалів та установок людини. Чим повніша професійна спрямованість, тим більш різностороннім є сенс для людини цього виду діяльності та задоволення від реалізації конкретного наміру.

Основними функціями професійної спрямованості майбутнього соціального працівника визначено: мотивацію навчання та самонавчання у вищому навчальному закладі; стимулювання опанування практичними уміннями та навичками майбутньої професійної діяльності; виховання та самовиховання усіх інших якостей особистості майбутнього соціального працівника, його здібностей; прискорення формування відповідальності та активності студента в усіх видах діяльності.

Отже, професійну спрямованість майбутнього соціального працівника дослідники розглядають переважно як систему особистісних якостей, які визначають внутрішнє розуміння мети й завдань професійної діяльності і які залежать від системи усталених домінуючих мотивів, ціннісних орієнтацій особистості молодої людини, що виражається в усвідомленому виборі професії соціального

\footnotetext{
${ }^{11}$ Мерлин В.С. Очерк психологи личности. Пермь : Книжное изд-во, 1959. 173 с.

12 Платонов К.К. К проблеме человеческой деятельности. Москва : Наука, 1998. $354 \mathrm{c}$.
} 
працівника, потребі оволодіти нею та досягти успіху в професійній діяльності.

Узагальнюючи різні погляди на зміст професійної спрямованості особистості, можна виокремити сутнісні характеристики професійної спрямованості майбутнього соціального працівника:

- професійна спрямованість майбутнього соціального працівника - це складна (комплексна) якість особистості, що виникає на певному етапі ऑii розвитку в результаті соціалізації (професіоналізації), структура якої зумовлена структурою і функціями професійної діяльності, соціальними вимогами до професійних і особистісних якостей соціальних працівників;

- професійна спрямованість майбутнього соціального працівника інтегрує відповідні професії складники мотиваційно-ціннісної сфери (потреби, мотиви, інтереси, ціннісні орієнтації, схильності) і виявляється у вибірковому ставленні особистості до світу професій загалом і до професії соціального працівника зокрема;

- професійна спрямованість майбутнього соціального працівника $\epsilon$ невіддільним складником професійної готовності фахівця, яка визначає мотивацію оволодіння професійною діяльністю, індивідуальний стиль та ефективність ії виконання;

- професійна спрямованість майбутнього соціального працівника виступає важливим мотиваційним чинником, що спонукає особистість до систематичного аналізу процесу та результатів власної діяльності, самооцінки професійно важливих якостей і постійного професійного самовдосконалення, підвищення рівня фахової майстерності;

- розвиток професійної спрямованості майбутнього соціального працівника є складним, тривалим і динамічним процесом, який триває протягом усього періоду професійної підготовки і трудової діяльності особистості та проходить через ряд послідовних стадій: виникнення і формування професійних намірів, професійне навчання, професійна адаптація, повна або часткова самореалізація особистості у праці.

\section{2. Педагогічні умови формування професійної спрямованості майбутніх соціальних працівників}

Формування професійної спрямованості майбутніх соціальних працівників краще здійснюється під впливом певних умов. Умовою, за тлумачним словником української мови, є обставини, особливості реальної дійсності, за яких відбувається або здійснюється що-небудь, а також правила, які існують або встановлені в тій чи іншій галузі 
життя, діяльності, які забезпечують нормальну роботу чого-небудь ${ }^{13}$. Філософський енциклопедичний словник категорію «умова» трактує як: середовище, у якому перебувають і без якого не можуть існувати предмети та явища; обставини, за яких щось відбувається; зазначені вимоги, яких потрібно дотримуватись. Зазначені підходи до поняття «умови» характеризують його як «щось зовнішне відносно до явища, на відміну від більш широкого поняття причини, до складу якого входять як зовнішні, так і внутрішні фактори». Педагогічні умови і шляхи формування та корекції формування професійної спрямованості майбутніх фахівців розглядали М. Дяченко, Е. Зеєр, С. Зімічева, Н. Кузьміна, В. Сластьонін, В. Ткачов, Г. Томілова, А. Чорних, П. Шавір та інші. У педагогічній науці дефініція «умова» в найбільш загальній формі визначається як основа, наявність обставин, які сприяють досягненню поставлених цілей, або, навпаки, гальмують їх досягнення. Педагогічні умови - це сукупність об'єктивних можливостей змісту, форм, методів і матеріального середовища, спрямованих на розв'язання поставлених завдань.

На основі здійсненого аналізу суттєвого змісту понять «умови» i «педагогічні умови» вважаємо, що педагогічними умовами формування професійної спрямованості майбутніх соціальних працівників є спеціально створені обставини, за яких відбувається стимулювання прагнення майбутніх соціальних працівників до самореалізації, професійного зростання і розвитку в галузі соціальної роботи. Нами визначено педагогічні умови професійної спрямованості майбутніх соціальних працівників. Перша педагогічна умова спрямування мотиваційної сфери майбутніх соціальних працівників на здобуття професії соціального працівника. Друга педагогічна умова формування ціннісного ставлення до професії соціального працівника. Третя педагогічна умова - оволодіння майбутніми соціальними працівниками професійними знаннями і вміннями.

Перша педагогічна умова - спрямування мотиваційної сфери майбутніх соціальних працівників на здобуття професії соціального працівника. Поштовхом особистості до здобуття професії соціального працівника $є$ незадоволені потреби або нереалізовані мотиви. Мотив $є$ усвідомленим спонуканням, яке зумовлює цілеспрямовану діяльність. Активним у здобутті професії соціального працівника буде той студент, який усвідомлює потребу в знаннях, необхідних у майбутній

13 Великий тлумачний словник сучасної української мови / автор, керівник проекту і головний редактор В. Т. Бусел. Київ : Видавничий дім «КиєвоМогилянська академія», 2004. 429 с. 
професійній діяльності, а свою професію усвідомлює як єдине або основне джерело задоволення власних матеріальних і духовних потреб.

Розглядаючи мотивацію навчальної діяльності, нами з'ясовано, що поняття «мотив» тісно пов'язане з поняттями «мета» і «потреба».

У структурі особистості майбутнього соціального працівника вони взаємодіють i отримали назву «мотиваційна сфера». Термін «мотиваційна сфера» охоплює всі види спонукань: усвідомлені (потреби, інтереси, цілі, стимули, мотиви, нахили) і неусвідомлені (прагнення, установки, бажання, інстинкти). Мотивація пронизує всі основні структурні утворення особистості: спрямованість, характер, емоції, здібності, діяльність, психічні процеси.

Характеризуючи мотивацію майбутнього соціального працівника доцільно говорити про навчальну i про навчально-професійну мотивацію, у якій закладена професійна спрямованість і готовність майбутнього соціального працівника до вирішення професійних завдань. Мотивація навчально-професійної діяльності - це співвідношення цілей, які майбутній фахівець прагне досягти, і внутрішньої активності його особистості. У навчанні мотивація виражається в прийнятті майбутнім соціальним працівником цілей і завдань навчання як особистісно значущих та необхідних.

Варто зазначити, що, виявляючи мотиви, які спрямовують майбутнього соціального працівника на здобуття професії, слід зважити на пізнавальні мотиви, які визначають прагнення до досконалого володіння знаннями, уміннями й навичками професійної діяльності; на соціальні мотиви, які виявляються в самоствердженні, у виявленні свого соціального статусу у навчанні; на професійні мотиви, які виявляються у прагненні до оволодіння обраною професією.

Є. Ільїн ${ }^{14}$ вважає, що на етапі оволодіння професією мотивація, пов'язана з інтересом до професії, виступає як ресурс і передумова, які необхідні для розвитку професіоналізму. Іншими словами, майбутньому соціальному працівнику необхідні стійкі професійні мотиви навчальної діяльності і цілком адекватні уявлення про свою майбутню роботу. Інтерес - це один із багатьох психологічних феноменів, що збуджують активність людини, як зазначають філософи, соціологи, психологи та педагоги.

Слово «інтерес» - латинського походження, у перекладі означає «бути важливим», «мати значення». Потреба тільки тоді породжує інтерес, коли ії задоволення ускладнюється тими чи іншими суб'єктивними факторами. Таким чином, інтереси виражають протиріччя між потребами та умовами їх виконання. Коли потреба

${ }^{14}$ Ильин Е. П. Мотивация и мотивы. Санкт-Петербург : Питер, 2002. 512 с. 
породжує інтерес, неминуче з'являється мета діяльності; «мета» та «інтерес» - поняття одного порядку. Потреби набувають усвідомленої, «смислотворної» сили завдяки інтересу, тобто шляхом повного розуміння сутності потреб та способів їх задоволення, у результаті чого мотиваційний процес отримує чітко визначену спрямованість. Завдяки інтересу здійснюється перехід від об'єктивного до суб'єктивного.

Сутність інтересу розуміють як вибіркову спрямованість, звернену на процес пізнання його предметної сторони; як тенденцію, прагнення, потребу особистості займатися саме цією діяльністю, яка приносить задоволення; як збуджувача активності особистості, у результаті чого діяльність стає привабливою, продуктивною; як особливе вибіркове ставлення до навколишнього середовища, явищ, процесів відповідно до їх життєвої значущості та емоційної привабливості. Інтерес до навчання не виникає стихійно, навчально-пізнавальні мотиви формуються у процесі самої навчальної діяльності.

До основних факторів, що впливають на формування позитивної стійкої мотивації до навчальної діяльності, відносить: зміст навчального матеріалу, організацію навчальної діяльності, колективні форми навчальної діяльності, оцінку навчальної діяльності, стиль педагогічного спілкування.

Друга педагогічна умова - формування ціннісного ставлення до професії соціального працівника. Для формування зрілих життєвих планів майбутніх соціальних працівників, їх особистісного й професійного самовизначення потрібна певна система цінностей особистості. Ціннісні орієнтації - це елементи структури особистості, що характеризують змістову сторону іiі спрямованості. У формі ціннісних орієнтацій у результаті визначення цінностей фіксується істотне, найбільш важливе для людини. Ціннісні орієнтації - це стійкі, інваріантні утворення моральної свідомості, основні його ідеї, поняття, «ціннісні блоки», компоненти світогляду, що виражають суть моральності людини, а отже, і загальні культурно-історичні умови й перспективи. Зміст їх змінюється і рухливий. Система ціннісних орієнтацій $€$ «згорнутою» програмою життєдіяльності слугує підгрунтям для реалізації визначеної моделі особистості.

Формування ціннісного ставлення до майбутньої професійної діяльності залежить від усвідомлення суті самого поняття «цінність», «ціннісне ставлення», адже вони є складними, багатогранними за змістом та формою виявлення. Цінність це значущість, якої набуває дійсність стосовно людини. Ціннісне ставлення визначається як внутрішня позиція особистості, що відображає взаємозв'язок особистісних і суспільних значень. Ціннісне ставлення розкриває 
внутрішній світ особистості, основними складниками якого є стійкий зміст та особистісні цінності як джерело цього змісту.

Ціннісне ставлення до майбутньої професійної діяльності можливе за умови його усвідомлення, прийняття та реалізації у практичній діяльності. Ціннісне ставлення студентів до майбутньої професійної діяльності визначають як цілісне, інтегративне утворення в структурі особистості майбутнього соціального працівника, сутність якого полягає: в усвідомленні соціальної значущості діяльності соціального працівника; наявності стійких професійних інтересів до праці соціального працівника; прагненні до творчої професійної діяльності. Формування ціннісного ставлення до майбутньої професійної діяльності є складним та багатогранним процесом, що має певні етапи вибір професії, отримання професійних знань та виявлення на основі цього інтересу до професійної діяльності, перші самостійні кроки студентів до оволодіння професійними вміннями та навичками, розвитку накопиченого особистого досвіду в педагогічній діяльності.

Це відбувається в процесі виховання та соціалізації особистості та залежить від багатьох факторів як об'єктивного, так і суб'єктивного характеру. Об'єктивні фактори існують незалежно від нашої свідомості, i тому цілеспрямовано вплинути на їх зміни повністю дослідники не можуть, а суб'єктивні фактори підлягають змінам і в результаті певного виховного впливу на них можливе отримання позитивних результатів.

До об'єктивних факторів формування ціннісного ставлення до майбутньої професійної діяльності відносять: рівень престижності, ставлення до даної професії в суспільстві, можливість професійної мобільності, рівень матеріальної винагороди за професійну працю та ін. Суб’єктивними факторами є: інтерес до обраної професії, психологічні особливості характеру та темпераменту особистості, можливість людини пов'язати своє життя з певним видом професійної діяльності. Особливе місце в ієрархії суб'єктивних факторів займає професійне виховання, оскільки саме воно $\epsilon$ регульованим, цілеспрямованим процесом формування професійної самосвідомості, розвитку професійних інтересів та культури.

Ціннісне ставлення до професійної діяльності проявляється найчастіше: в прийнятті особистістю об'єктивних цілей діяльності для управління власної участі в ній; у розумінні особистістю змісту діяльності, яка виконується; в активній участі особистості в діяльності; в практичному оволодінні особистістю різноманітними способами виконання певного виду діяльності. Ціннісне ставлення до майбутньої професійної діяльності формується через усвідомлення особистістю значущості цієї діяльності, розвиток у неї стійких професійних 
інтересів, емоційне переживання результатів своєї праці, виховання прагнення до активної творчої праці.

У низці досліджень зазначається, що студентство - це період сенситивний, дуже сприятливий для утворення ціннісних орієнтацій як стійкої якості особистості, що сприяе становленню світогляду та ставленню до довкілля. Ціннісні орієнтації регулюють і спрямовують діяльність майбутніх соціальних працівників. А цінності як суворий контролер їх бажань спонукають до самопізнання, самовдосконалення, самовизначення.

Сучасна людина успішно поєднує в собі спрямованості 3 різних сфер життя та виробничої діяльності, що дозволяє їй гнучко реагувати на різні ситуації, що виникають в соціумі. Тому навчання у вищому навчальному закладі повинно забезпечувати такий розвиток, внаслідок якого формується не тільки спрямованість на професію, яку здобувають майбутні соціальні працівники, а й розвивається усвідомлення, що для того, щоб бути успішним, необхідно мати або розвивати в собі ще й інші важливі для життя моральні та соціальні якості, знання, вміння, навички. Ціннісне ставлення до майбутньої професійної діяльності - це одна з необхідних якостей не лише фахівця з вищою освітою, а й високоморальної особистості.

Третя педагогічна умова - оволодіння майбутніми соціальними працівниками професійними знаннями $\mathrm{i}$ вміннями. Професійна спрямованість особистості майбутнього соціального працівника характеризується системою вмінь і навичок із психолого-педагогічних, методичних та фахових дисциплін, що забезпечують реалізацію професійних планів, цілей, активність майбутніх соціальних працівників у професійній діяльності.

Узагальнюючи результати наукових пошуків дослідників у соціальній сфері з'ясовано, що виконання професійних обов'язків потребує наявності i усвідомлення професійних здібностей до майбутньої діяльності. Професійна спрямованість особистості майбутнього соціального працівника характеризується уміннями i навичками, серед яких: організаційні вміння і навички (вміння організовувати власну діяльність, уміло застосовувати елементи взаємодії та співпраці); фахові (науково й методично підходити до відбору змісту та обсягу навчальної інформації відповідно до програми й теми 3 навчального предмета, оперувати оптимальними формами, методами, засобами навчально-виховної діяльності); комунікативні (налагоджувати спілкування 3 клієнтами й колегами на основі взаєморозуміння, взаємоповаги, емпатії та партнерства); проективні (вміти планувати власну професійну діяльність, визначати мету й основні завдання, діагностувати навчально-виховні ситуації, ефективно 
й коректно проектувати свої подальші професійні дії); рефлексивнотворчі (бути здатним до гуманного сприйняття педагогічного оточення, аналізувати власну професійну діяльність, прогнозувати майбутні дії).

\section{ВИСНОВКИ}

Аналіз психолого-педагогічних досліджень, присвячених проблемі спрямованості особистості, дає підстави стверджувати, що професійна спрямованість $є$ комплексною якістю особистості, структура якої зумовлена функціями професійної діяльності, соціальними вимогами до професійних і особистісних якостей відповідної категорії фахівців. Професійна спрямованість інтегрує складники мотиваційно-ціннісної сфери (потреби, мотиви, інтереси, ціннісні орієнтації, схильності) і виявляється у вибірковому ставленні особистості до світу професій загалом і до конкретної обраної професії зокрема.

Професійна спрямованість майбутнього соціального працівника може трактуватися як інтегрована характеристика, в якій виражається прагнення соціального працівника до самореалізації, професійного зростання і розвитку в галузі професійної діяльності; як система емоційно-ціннісних ставлень, що визначає структуру стійких домінуючих мотивів особистості соціального працівника (інтересів, нахилів, переконань тощо), що спонукають до утвердження в професійній діяльності та спілкуванні; як прагнення особистості стати, бути i залишатися соціальним працівником, долати перешкоди та труднощі у своїй роботі.

Педагогічними умовами формування професійної спрямованості майбутніх соціальних працівників $\epsilon$ спеціально створені обставини, за яких відбувається стимулювання прагнення майбутніх соціальних працівників до самореалізації, професійного зростання і розвитку в галузі соціальної роботи. Педагогічними умовами формування професійної спрямованості майбутніх соціальних працівників визначаємо: спрямування мотиваційної сфери майбутніх соціальних працівників на здобуття професії соціального працівника; формування ціннісного ставлення до професії соціального працівника; оволодіння майбутніми соціальними працівниками професійними знаннями i вміннями.

\section{АНОТАЦІЯ}

Статтю присвячено одній із актуальних проблем підготовки майбутніх фахівців соціальної сфери - визначенню педагогічних умов формування професійної спрямованості майбутніх соціальних працівників. Зокрема, розкрито сутність поняття професійна спрямованість, проаналізовано функціональні характеристики та 
основні групи мотивів, які лежать в основі професійної спрямованості особистості.

Висвітлено категоріальну сутність професійної спрямованості майбутнього соціального працівника, виходячи з його соціальної ролі. Визначено основні функції професійної спрямованості майбутнього соціального працівника. Виокремлено сутнісні характеристики професійної спрямованості майбутнього соціального працівника.

Здійснено аналіз суттєвого змісту понять «умови» і «педагогічні умови». Визначено педагогічні умови формування професійної спрямованості майбутніх соціальних працівників як спеціально створені обставини, за яких відбувається стимулювання прагнення майбутніх соціальних працівників до професійного зростання i розвитку в галузі соціальної роботи. Зосереджено увагу на розкритті особливостей педагогічних умов формування професійної спрямованості майбутніх соціальних працівників, серед яких: спрямування мотиваційної сфери майбутніх соціальних працівників на здобуття професії соціального працівника; формування ціннісного ставлення до професії соціального працівника; оволодіння майбутніми соціальними працівниками професійними знаннями і вміннями.

\section{ЛІТЕРАТУРА}

1. Бахмат Л.В. Готовність до професійної педагогічної діяльності як наукова проблема. Педагогіка формування творчої особистості у вищій $і$ загальноосвітній школах. 2014. Вип. 34. С. 56-60.

2. Борытко Н.M. Воспитание профессионально-трудовой направленности учащихся старших классов гимназии : автореф. дис. ... канд. пед. наук : 13.00.07. Волгоград, 1992. 19 с.

3. Великий тлумачний словник сучасної української мови / автор, керівник проекту і головний редактор В. Т. Бусел. Київ : Видавничий дім «Києво-Могилянська академія», 2004. 429 с.

4. Зеер Э.Ф. Психология профессионального развития : учеб. пособ. для студентов высших учебных заведений. Москва : Издательський центр «Академия», 2007. 240 с.

5. Зыбина Л.Н. Структурные компоненты и динамики профессиональной направленности личности : дис. ... канд. психол. наук : 19.00.01. Новосибирск, 2009. 317 с.

6. Ильин Е.П. Мотивация и мотивы. Санкт-Петербург : Питер, 2002. $512 \mathrm{c}$.

7. Мерлин В.С. Очерк психологи личности. Пермь : Книжное изд-во, 1959. $173 \mathrm{c}$.

8. Платонов К.К. К проблеме человеческой деятельности. Москва : Наука, 1998. 354 с. 
9. Профконсультационная работа со старшеклассниками / под. ред. Б.А. Федоришина. Москва, 2000. 172 с.

10. Прядун В.О. Поняття професійної спрямованості майбутнього вчителя математики. Наукові записки Серія: Проблеми методики фізико-математичної і технологічної освіти. 2013. № 9. С. 27-31.

11. Психологическое сопровождение выбора профессии: науч.метод. пособие / под. ред. Л.М. Митиной. М, 1998. 184 с.

12. Рубинштейн С.Л. Проблемы общей психологи. Москва, 1946. $623 \mathrm{c}$.

13. Шавир П.А. Психология профессионального самоопределения в ранней юности. Москва : Педагогіка, 19981.96 с.

14. Шевченко Л.М. Професійна спрямованість: методологічний аспект. Науковий вісник. Київ, 2005. Вип. 88. С. 204-215.

\section{Information about the authors:}

Ionova I. M.,

Ph.D. in Pedagogic Sciences,

Assistant Professor at the Department of Social Work and Management of Sociocultural Activity Anton Makarenko Sumy State Pedagogic University 89, Romenska Str., Sumy, Ukraine ORCID ID: orcid.org/0000-0001-9284-9308

Polianychko A. O.,
Ph.D. in Pedagogic Sciences,
Assistant Professor at the Head of the Department of Social Work and
Management of Sociocultural Activity
Anton Makarenko Sumy State Pedagogic University
89, Romenska Str., Sumy, Ukraine
ORCID ID: orcid.org/0000-0003-3729-3452

